\title{
Pheromone trapping of the double-spined bark beetle Ips duplicatus (Coleoptera: Curculionidae, Scolytinae): seasonal variation in abundance
}

\author{
Jaroslav Holuša ${ }^{1}$, Wojciech Grodzki ${ }^{2}$, Karolina Lukašová ${ }^{1} \bowtie$, Jan Lubojacký $y^{1,3}$ \\ ${ }^{1}$ Czech University of Life Sciences, Faculty of Forestry and Wood Sciences, Kamýcká 129, 16521 Prague, Czech Republic, \\ phone: +420737322550, email: karolina.lukasova@gmail.com \\ ${ }^{2}$ Forest Research Institute, Department of Mountain Forestry, Fredry 39, 30-605 Kraków, Poland \\ ${ }^{3}$ Forestry and Game Management Research Institute, Prague, Office Frýdek-Místek, Na Půstkách 39, \\ 73801 Frýdek-Místek, Czech Republic
}

\begin{abstract}
Ips duplicatus adults were sampled with pheromone-baited black window-slot traps (Theysohn) in 70- to 100-yearold Norway spruce (Picea abies) stands between 280 and $650 \mathrm{~m}$ a.s.l. in the eastern Czech Republic and southern Poland during 2000-2010. Sets of 5-12 traps were placed about $20 \mathrm{~m}$ from the edge of the infested forest. Each trap was baited with a standard synthetic pheromone lure (ID Ecolure), and was setup 1.5-2.0 m above the ground. The objectives were to determine the relationship between the numbers of adults trapped in the overwintered generation and those in the offspring generation. According to data from 135 traps, the numbers of overwintered beetles captured in spring (April-June) were significantly higher than the numbers captured in summer (July-August), but the numbers of offspring beetles captured in summer were significantly correlated with the numbers overwintered beetles captured in spring. The spring captures can be used to estimate the threat caused by I. duplicatus during the whole vegetation season. The traps installed in summer should be used to determine the peaks in the bark beetle flight activity, thus enabling early identification of trees infested by I. duplicatus, especially inside stands.
\end{abstract}

\section{KeY WORDS}

central Europe, flight activity, generation, Ips duplicatus, pheromone lure

\section{INTRODUCTION}

The double-spined bark beetle, Ips duplicatus (Sahlberg 1836), is naturally distributed in the northern part of the Europe, from Sweden through Finland and Siberia, reaching as far as Sakhalin (Pfeffer and Knížek 1995). It is naturally present in northern Poland
(Karpiński 1935), however considered an invasive species e.g. in Slovakia (Zúbrik et al. 2006). It is listed as a quarantine pest by the European Union and the European and Mediterranean Plant Protection Organisation (Smith et al. 1996), but also exists on some lists of protected species (e.g., Bussler and Bense 2003). Local outbreaks of $I$. duplicatus were recorded in Poland and 
the Czech Republic in the 1990s (Knížek and Zahradník 1996; Grodzki 1997, 2003), but I. duplicatus has also been regarded as a major cause of damage in natural spruce forests in Inner Mongolia, China, where outbreaks of this beetle have frequently occurred since the 1950s (Zhang and Schlyter 1995; Schlyter et al. 2001; Zhang et al. 2001).

The life cycle of I. duplicatus is generally similar to that of I. typographus (L.) (Holuša et al. 2003), however some differences exist. The spring swarming in I. duplicatus can occur earlier and more rapidly than that of I. typographus (Grodzki 1998), as in I. $d u$ plicatus the adult is the only overwintering stadium (Schnaider and Sierpiński 1955). It may co-occur with I. typographus on the same trees, usually infesting the upper parts of stems. However, in epidemic conditions I. duplicatus competes with I. typographus for space, and it may then also be found on the middle and basal parts of stems (Grodzki 2012). In northern Europe (including northern Poland), I. duplicatus is univoltine (Schnaider and Sierpiński 1955), however in southern Poland and the Czech Republic a second, and sometimes third, generation can be produced (Mrkva 1995; Holuša et al. 2003). That is why, in epidemic conditions, this species is considered as a serious agent of mortality in Norway spruce (Grodzki 1997; Holuša and Liška 2003).

The last I. duplicatus outbreak in the Czech Republic began in 2003, and the numbers of trees to be infested and/or killed has remained high since 2005 (Holuša et al. 2010b); consequently, this species is now considered economically important in the Czech Republic. In Central Europe, I. duplicatus is spreading westward (Holuša et al. 2010b), as well as east and southward (Vakula et al. 2009).

The forecast and control of this pest is complicated, as the beetles usually attack the trees inside the forest stand, first establishing their galleries in the crown zone. Thus, the identification of infested trees is difficult, and usually delayed. Lying traps are not attractive to the beetles, and are ineffective (Sierpiński 1958). The use of pheromone-baited artificial traps however, may be a useful additional tool in actively protecting forests against $I$. duplicatus.

At present, there are several artificial pheromone lures available for this species, which differ in efficiency (Holuša et al. 2010a). Thanks to the develop- ment of these lures, it is possible to monitor the flight activity of $I$. duplicatus over large areas, even when the beetle is present in only small numbers (Grodzki 1998; Holuša et al. 2010b). According to these results, it appears that the number of beetles captured from the spring generation roughly correlates with the numbers of trees attacked throughout the whole year, albeit at the level higher than an individual stand. Some foresters see little worth in monitoring I. duplicatus during the summer.

The main goal of this study was to test if the summer captures correspond with the insect abundance in spring, in order to determine if it is necessary or worthwhile (from a practical point of view), to install pheromone traps during summer allowing capture the offspring generation.

\section{Methods}

Field trapping experiments were conducted in 70- to 100-year-old Norway spruce Picea abies (L.) Karst. stands located between 280 and $650 \mathrm{~m}$ a.s.l. in the eastern Czech Republic and southern Poland. Pheromonebaited black window-slot traps were used (Theysohn, Germany), each with a total active surface area of $4284 \mathrm{~cm}^{2}(42 \times 51 \mathrm{~cm}$ on two sides) (Niemeyer et al. 1983). Sets of 5-12 traps were placed about $20 \mathrm{~m}$ from the edge of the threatened forest, as recommended by Chen et al. (2010). The traps in each set were oriented along a line parallel to the forest edge and deployed $1.5-2.0 \mathrm{~m}$ above the soil surface at a distance of $15 \mathrm{~m}$ apart, which was sufficient to minimise the overlap of pheromone plumes. Each trap was baited with a standard synthetic pheromone lure (ID Ecolure, Fytofarm, Slovakia). One set of traps was deployed for each locality and year (tab. 1).

Seasonal flight activity of $I$. duplicatus in the spruce forests was monitored during the entire growing season in: 2000 (data were published in Holuša et al. 2010b), 2001, 2004 (Holuša et al. 2006), 2005 (Holuša et al. 2006), 2006 (Holuša et al. 2007), 2008 (Holuša et al. 2010a), and 2010; a total of 135 traps in total (tab. 1). Each year, the traps and lures were deployed at the end of April and checked every week until the end of September. The lures were refreshed after 8 weeks. 
Tab. 1. Location of the experimental sites in Czech Republic and Poland

\begin{tabular}{|c|c|c|c|c|}
\hline Locality & Coordinates & $\begin{array}{c}\text { Altitude } \\
\text { (m asl) }\end{array}$ & Year & $\begin{array}{l}\text { Number } \\
\text { of traps }\end{array}$ \\
\hline Zimna Wódka & $\begin{array}{l}50^{\circ} 27^{\prime} \mathrm{N} ; \\
18^{\circ} 17^{\prime} \mathrm{E}\end{array}$ & 280 & 2000 & 10 \\
\hline Zimna Wódka & $\begin{array}{c}50^{\circ} 27^{\prime} \mathrm{N} ; \\
18^{\circ} 17^{\prime} \mathrm{E}\end{array}$ & 280 & 2001 & 11 \\
\hline Široká Niva & $\begin{array}{c}50^{\circ} 04^{\prime} \mathrm{N} ; \\
17^{\circ} 28^{\prime} \mathrm{E}\end{array}$ & 650 & 2004 & 5 \\
\hline Horní Benešov & $\begin{array}{c}49^{\circ} 59^{\prime} \mathrm{N} ; \\
17^{\circ} 34^{\prime} \mathrm{E}\end{array}$ & 650 & 2004 & 10 \\
\hline Leskovec & $\begin{array}{c}49^{\circ} 53^{\prime} \mathrm{N} ; \\
17^{\circ} 36^{\prime} \mathrm{E}\end{array}$ & 570 & 2004 & 10 \\
\hline Břidličná & $\begin{array}{c}49^{\circ} 57^{\prime} \mathrm{N} ; \\
17^{\circ} 24^{\prime} \mathrm{E}\end{array}$ & 580 & 2004 & 10 \\
\hline Bruntál & $\begin{array}{c}49^{\circ} 58^{\prime} \mathrm{N} ; \\
17^{\circ} 26^{\prime} \mathrm{E}\end{array}$ & 590 & 2004 & 10 \\
\hline Široká Niva & $\begin{array}{l}50^{\circ} 04^{\prime} \mathrm{N} ; \\
17^{\circ} 28^{\prime} \mathrm{E}\end{array}$ & 650 & 2005 & 5 \\
\hline Horní Benešov & $\begin{array}{c}49^{\circ} 59^{\prime} \mathrm{N} ; \\
17^{\circ} 34^{\prime} \mathrm{E}\end{array}$ & 650 & 2005 & 10 \\
\hline Leskovec & $\begin{array}{c}49^{\circ} 53^{\prime} \mathrm{N} ; \\
17^{\circ} 36^{\prime} \mathrm{E}\end{array}$ & 570 & 2005 & 10 \\
\hline Břidličná & $\begin{array}{c}49^{\circ} 57^{\prime} \mathrm{N} \\
17^{\circ} 24^{\prime} \mathrm{E}\end{array}$ & 580 & 2005 & 10 \\
\hline Bruntál & $\begin{array}{c}49^{\circ} 58^{\prime} \mathrm{N} ; \\
17^{\circ} 26^{\prime} \mathrm{E}\end{array}$ & 590 & 2005 & 10 \\
\hline Pustá Polom & $\begin{array}{c}49^{\circ} 49^{\prime} \mathrm{N} ; \\
18^{\circ} 00^{\prime} \mathrm{E}\end{array}$ & 430 & 2006 & 7 \\
\hline Václavovice & $\begin{array}{c}49^{\circ} 45^{\prime} \mathrm{N} ; \\
18^{\circ} 21^{\prime} \mathrm{E}\end{array}$ & 305 & 2008 & 12 \\
\hline Pustá Polom & $\begin{array}{c}49^{\circ} 50^{\prime} \mathrm{N} \\
18^{\circ} 01^{\prime} \mathrm{E}\end{array}$ & 395 & 2010 & 5 \\
\hline
\end{tabular}

In most years, two periods of I. duplicatus seasonal flight activity (corresponding with the flight of two generations) could easily be distinguished (Holuša et al. 2006, 2007, 2010a), and only data from those years were analysed. I. duplicatus has two or three generations per year with the main peaks of bark beetle emergence in April/May, July, and August/September (Holuša et al. 2003, 2006, 2007, 2010a). The years in which three flight peaks were detected (2002 and 2003), were excluded because it seemed likely that the third peak was caused by either a third generation or by a sister brood. These sister broods (or "re-emerging" beetles) can cause a third peak in flight activity (see Holuša et al.
2003). Because two main peaks were visible (firstly in May, and secondly in July) on all flight activity curves, we divided the numbers of beetles caught during the vegetation season to the overwintered (flight in AprilJune), and offspring (flight in July-August) generations.

The mean number of overwintered beetles trapped in April-June was regressed on the mean number of offspring beetles trapped in July-August in each locality and year. Data were log transformed and fit by linear regression, and the numbers of individuals captured in each generation were compared by Wilcoxon pair tests in Statistica 9.0.

\section{Results}

During the whole trapping period (2000-2010) a total of 291,891 adults were captured. The numbers of beetles captured differed between individual years (tab. 2). Overall the mean numbers of beetles captured in AprilJune, during the first flight $(854.7 \pm 681.8$ beetles per trap), were significantly higher than the numbers of beetles captured in July-August, i.e. during the second flight $(579.0 \pm 555.1$ beetles per trap) (Wilcoxon pair test; $\mathrm{T}=34 ; \mathrm{Z}=2.01 ; \mathrm{p}<0.05)$, although the differences are not significant across all localities and years (tab. 2). The I. duplicatus beetles in the overwintered generation (the first flight), represented about $60 \%$ of all the beetles trapped in the whole growing season of a given year,

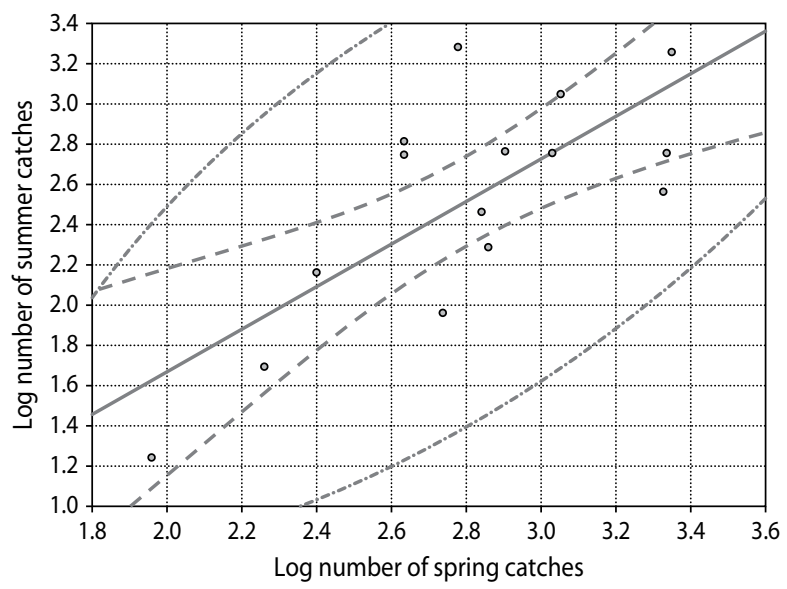

Fig. 1. Correlation between numbers of Ips duplicatus trapped in the summer monitoring period (July-August), and the number trapped in spring (April-June) $(\mathrm{y}=-0.44+1.05 \mathrm{x}$; $\mathrm{r}=0.74 ; \mathrm{p}<0.01)$ 
Tab. 2. Number of Ips duplicatus beetles captured in individual localities and years, and comparison of April-June and July-August abundances by Wilcoxon pair test (z-values)

\begin{tabular}{|c|c|c|c|c|c|c|c|c|}
\hline Year & Period & Locality & Median & Minimum & Maximum & $25 \%$ & $75 \%$ & $\mathrm{z}$ \\
\hline \multirow{2}{*}{2000} & April-June & \multirow{2}{*}{ Zimna Wódka } & 153 & 97 & 341 & 115 & 252 & \multirow{2}{*}{$3.70^{* * *}$} \\
\hline & July-August & & 48 & 13 & 178 & 21 & 68 & \\
\hline \multirow{2}{*}{2001} & April-June & \multirow{2}{*}{ Zimna Wódka } & 91 & 48 & 133 & 48 & 133 & \multirow{2}{*}{$2.20^{*}$} \\
\hline & July-August & & 18 & 17 & 18 & 17 & 18 & \\
\hline \multirow{2}{*}{2004} & April-June & \multirow{2}{*}{ Široká Niva } & 646 & 62 & 1755 & 308 & 821 & \multirow{2}{*}{$2.02^{*}$} \\
\hline & July-August & & 67 & 10 & 460 & 21 & 420 & \\
\hline \multirow{2}{*}{2004} & April-June & \multirow{2}{*}{ Horní Benešov } & 1152 & 120 & 5795 & 395 & 3118 & \multirow{2}{*}{$2.19^{*}$} \\
\hline & July-August & & 245 & 56 & 1150 & 100 & 680 & \\
\hline \multirow{2}{*}{2004} & April-June & \multirow{2}{*}{ Leskovec } & 625 & 14 & 10915 & 479 & 4610 & \multirow{2}{*}{$1.99^{*}$} \\
\hline & July-August & & 310 & 37 & 1324 & 100 & 415 & \\
\hline \multirow{2}{*}{2004} & April-June & \multirow{2}{*}{ Břidličná } & 1248 & 113 & 2890 & 720 & 1527 & \multirow{2}{*}{$2.80^{* *}$} \\
\hline & July-August & & 210 & 10 & 980 & 176 & 560 & \\
\hline \multirow{2}{*}{2004} & April-June & \multirow{2}{*}{ Bruntál } & 713 & 236 & 5570 & 300 & 1290 & \multirow{2}{*}{1.07 n.s. } \\
\hline & July-August & & 980 & 600 & 4400 & 840 & 1504 & \\
\hline \multirow{2}{*}{2005} & April-June & \multirow{2}{*}{ Široká Niva } & 360 & 60 & 400 & 70 & 360 & \multirow{2}{*}{1.10 n.s. } \\
\hline & July-August & & 105 & 25 & 400 & 75 & 120 & \\
\hline \multirow{2}{*}{2005} & April-June & \multirow{2}{*}{ Horní Benešov } & 557 & 57 & 1051 & 247 & 695 & \multirow{2}{*}{1.58 n.s. } \\
\hline & July-August & & 275 & 100 & 2070 & 115 & 445 & \\
\hline \multirow{2}{*}{2005} & April-June & \multirow{2}{*}{ Leskovec } & 520 & 43 & 3480 & 100 & 1010 & $076 \mathrm{ng}$ \\
\hline & July-August & & 863 & 20 & 1995 & 60 & 1190 & 0.1011 .5 \\
\hline 2005 & April-June & Břidličná & 361 & 80 & 2110 & 160 & 465 & $255^{*}$ \\
\hline 2000 & July-August & 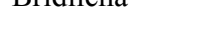 & 105 & 15 & 850 & 30 & 220 & 2.00 \\
\hline 2005 & April-June & Rruntól & 355 & 45 & 1250 & 275 & 563 & $160 \mathrm{~ns}$ \\
\hline 2005 & July-August & Druital & 485 & 80 & 1740 & 365 & 790 & $1.00 \mathrm{ll} . \mathrm{s}$ \\
\hline 2006 & April-June & Pustá Polom & 453 & 89 & 1436 & 306 & 726 & $220^{*}$ \\
\hline & July-August & & 68 & 29 & 178 & 39 & 166 & 2.20 \\
\hline 2008 & April-June & Václayovice & 1126 & 547 & 6909 & 639 & 3632 & $267^{*}$ \\
\hline 2000 & July-August & vactavovice & 381 & 123 & 1806 & 226 & 829 & 2.01 \\
\hline 2010 & April-June & Pustó Polom & 484 & 140 & 2687 & 390 & 1898 & $\mathrm{n}_{\mathrm{S}}$ \\
\hline 2010 & July-August & Pusta POIOM & 1202 & 798 & 1354 & 1008 & 1211 & i.s. \\
\hline
\end{tabular}

Significance of differences: ${ }^{*}-\mathrm{p}<0.05 ; * *-\mathrm{p}<0.01, * * *-\mathrm{p}<0.001$, n.s. - not significant.

and this percentage varied in individual localities and years of study (within a range of 50-91\%) (tab. 2).

A linear regression between the numbers of beetles trapped in the offspring generation (July-August), and the numbers trapped in the overwintered generation (AprilJune), was conducted to fit the data (fig. 1). The number of overwintered I. duplicatus adults captured in the first flight was correlated with the number of offspring beetles captured in the second flight $(r=0.74 ; p<0.01)$.

\section{Discussion}

The seasonal patterns of captures in I. duplicatus appear to be very similar to those of I. typographus. The correlation between the number of captured overwintered and offspring beetles in I. duplicatus is consistent with data from I. typographus (Nef and Janssens 1986; Lindelöw and Schroeder 2001; Faccoli and Stergulc 2004; Grodzki 2007). Additionally the percentage of captured 
beetles from the overwintered population $(50-91 \%$ of the number from the whole year), corresponds with the range of 55-84\% reported for bivoltine I. typographus populations (Faccoli and Stergulc 2004; Grodzki 2007). Given that each I. duplicatus female deposits 46 eggs on average (Karpiński 1935), this drop in capture rate seems unusual. One explanation is that mortality may be higher for the second generation because of the effect of the host tree (Wermelinger 2004); and due to the increased predation of adults, as well as on eggs, larvae, and pupae (Otvos 1979), and the parasitism of immature stages (Weslien and Schroeder 1999; Wermerlinger 2002). Beside the supposed impact of natural enemies, the main reason why fewer adults are trapped in the summer than in the spring however, is probably that most bark beetles fly in the tree crowns in summer (Mrkva and Vala 2009, 2010), i.e. they are not attracted by artificial lures from distant traps, located close to the ground.

In any case, the number of I. duplicatus adults trapped in the summer (the offspring of the overwintered generation) was correlated with the number of beetles trapped in the spring (the overwintered generation), and very often far fewer adults were trapped in summer than in spring. According to the patterns identified in I. typographus, in the case of bivoltine populations, spring captures can be used to determine the threat from beetles during the whole vegetation season (Faccoli and Stergulc 2004; Grodzki 2007). It seems that in the case of bivoltine I. duplicatus populations a similar method can be applied. From this point of view the installation of artificial traps in the summer seems to be fruitless. On the other hand, the pheromone traps are considered as an effective tool for monitoring seasonal flight activity in bark beetles (Grodzki 2007), including I. duplicatus (Grodzki 1998; Holuša et al. 2003). Facing the difficulties in the control of this pest (especially in the identification of already infested trees), the current information about its flight activity can be very useful in order to define the peaks in captures, reflecting the flight period of a given generation. For this reason it is necessary to install the pheromone dispensers in the summer, when the captures can describe the threat similarly as in the spring. The relationship between the number of $I$. duplicatus trapped and the size of the population is unknown. Because felled trees are not attractive to I. duplicatus (Sierpiński 1958), and cannot be used to monitor or reduce I. duplicatus population density, pheromone traps might represent an important tool in monitoring this species (see also Schlyter et al. 2001). Monitoring of $I$. duplicatus with pheromone traps will thus enable forest managers to determine the beginning and end of summer flight activity, indicating the necessity of intensive penetration of spruce stands in order for the timely identification and removal of infested trees, which is very important especially in the areas where multivoltine populations of this species are present.

\section{Acknowledgements}

The investigation was supported by IGA No. 20124332 of the Faculty of Forestry and Wood Sciences, Czech University of Life Sciences and KUS QJ1220317 of the Ministry of Agriculture of the Czech Republic.

\section{References}

Bussler H., Bense U. 2003. Rote Liste gefährdeter Borkenkäfer (Coleoptera: Scolytidae), Breitrussler (Anthribidae) und Kernkäfer (Platypodidae) Bayerns. Bayerische Landesamt für Umweltschutz, 166, 172-173.

Chen G.F., Zhang Q.H., Wang Y.J., Liu G.T., Zhou X.M., Niu J.F., Schlyter F. 2010. Catching Ips $d u$ plicatus (Sahlberg) (Coleoptera: Scolytidae) with pheromone-baited traps: optimal trap type, colour, height and distance to infestation. Pest Management Science, 66, 213-219.

Faccoli M., Stergulc F. 2004. Ips typographus (L.) pheromone trapping in south Alps: spring catches determine damage thresholds. Journal of Applied Entomology, 128, 307-311.

Grodzki W. 1997. Możliwości kontroli liczebności populacji kornika zrosłozębnego Ips duplicatus C.R.Sahlb. na południu Polski. Sylwan, 11, 25-36.

Grodzki W. 1998. Próba zastosowania pułapek feromonowych do śledzenia liczebności populacji kornika zrosłozębnego Ips duplicatus C.R.Sahlb. (Col.: Scolytidae). Prace Instytutu Badawczego Leśnictwa, Seria A, 846, 95-109.

Grodzki W. 2003. Zasięg występowania kornika zrosłozębnego Ips duplicatus C.R.Sahlb. (Col.: Sco- 
lytidae) w obszarach górskich południowej Polski. Sylwan, 8, 29-36.

Grodzki W. 2007. Wykorzystanie pułapek feromonowych do monitoringu populacji kornika drukarza w wybranych parkach narodowych w Karpatach. Instytut Badawczy Leśnictwa, Rozprawy i monografie, 8, 1-127.

Grodzki W. 2012. Two types of Norway spruce Picea abies (L.) H. Karst. infestation by the double spined bark beetle Ips duplicatus C.R. Sahlb. (Coleoptera: Scolytinae) in southern and north-eastern Poland. Folia Forestalia Polonica, Series A Forestry, 54 (3), 169-174.

Holuša J., Grodzki W., Lukášová K. 2010a. Porównanie skuteczności dyspenserów feromonowych ID Ecolure, Pheagr IDU i Duplodor na kornika zrosłozębnego (Ips duplicatus). Sylwan, 154, 363-370.

Holuša J., Liška J. 2002. Hypotéza chřadnutí a odumírání smrkových porostů ve Slezsku (Česká republika). Zprávy Lesnického Výzkumu, 47, 9-15.

Holuša J., Lubojacký J., Knížek M. 2010b. Distribution of double-spined spruce bark beetle Ips duplicatus in the Czech Republic: Spreading in 1997-2009. Phytoparasitica, 38, 435-443.

Holuša J., Weiser J., Drápela K. 2007. Pathogens of Ips duplicatus (Coleoptera: Scolytidae) in three areas in Central Europe. Acta Protozoologica, 46, 157-167.

Holuša J., Voigtová P., Kula E., Křístek Š. 2006. Výskyt lýkožrouta severského (Ips duplicatus Sahlberg, 1836) (Coleoptera: Scolitidae) na LS Bruntál LČR, s.p., v roce 2004-2005. Zpravodaj ochrany lesa, 13, $1-46$.

Holuša J., Zahradník P., Knížek M., Drápela K. 2003. Seasonal flight activity of the double-spined spruce bark-beetle Ips duplicatus (Coleoptera, Curculionidae, Scolytinae) in Silesia (Czech Republic). Biológia (Bratislava), 58, 935-941.

Karpiński J.J. 1935. Przyczyny ograniczające rozmnażanie się korników drukarzy (Ips typographus L. i Ips duplicatus Sahlb.) w lesie pierwotnym. Instytut Badawczy Lasów Państwowych, Rozprawy i sprawozdania, Series A, 15, 1- 65.

Knížek M., Zahradník P. 1996. Mass Outbreak of Ips duplicatus Sahlberg (Coleoptera, Scolytidae). In: XX International Congress of Entomology - Proceedings, August 25-31 1996, Firenze, Italy (ed.: J. Doe).
Lindelöw Å., Schroeder L.M. 2001. Spruce bark beetle, Ips typographus (L.), in Sweden: monitoring and risk assessment. Journal of Forest Science, 47, 40-42.

Mrkva R. 1995. Nové poznatky o bionomii, ekologii a hubení lýkožrouta severského. Lesnická práce, 74, 5-7.

Mrkva R., Vala, V. 2009. Lýkožrout severský. Obrana proti významnému invaznímu škůdci. Lesnická práce, $88,78-80$.

Mrkva R., Vala V. 2010. Rojení lýkožroutů Ips typographus L. a Ips duplicatus Sahlb. Lesnická práce, 89, 585-587.

Nef L., Janssens R. 1986. Influence de divers types de pièges et de facteurs environnementaux sur les captures d'ipides forestiers. Mededelingen van de Faculteit Landbouwwetenschappen, Rijksuniversiteit Gent, 51/31a, 907-913.

Niemeyer H., Schroder T., Watzek G. 1983. Eine neue Lockstoff-Falle zur Bekämpfung von Rinden- und Holzbrütenden Borkenkäfern. Der Forst- und Holzwirt, 38, 105-112.

Otvos I.S. 1979. The effects of insectivorous bird activities in forest ecosystems: an evaluation. In: The role of insectivorous birds in forest ecosystems (eds.: J.G. Dickson, R.N. Connors, R.R. Fleet, J.A. Jackson, J.C. Kroll). Academic Press, New York, 341-374.

Schlyter F., Zhang Q.H., Liu G.T., Ji L.Z. 2001. A successful case of pheromone mass trapping of the bark beetle Ips duplicatus in a forest island, analysed by 20 -year time-series data. Integrated Pest Management Reviews, 6, 185-196.

Schnaider Z., Sierpiński Z. 1955. Z biologii kornika zrosłozębnego (Ips duplicatus Sahlb.). Roczniki Nauk Leśnych, 13, 59-68.

Sierpiński Z. 1958. Zagadnienie zwalczania kornika zrosłozębnego (Ips duplicatus Sahlb.). Sylwan, 102, 68-75.

Smith I.M., McNamara D.G., Scott P.R., Holderness M. 1996. Quarantine pests for Europe. CAB International, Wallingford, pp. 1425.

Vakula J., Brutovský D., Gubka A., Galko J., Kunca A. 2009. Vyhodnotenie monitoringu lykožrúta severského Ips duplicatus Sahlb. v roku 2009 v Lesoch SR, š. p. a niektorých neštátnych subjektoch. Národné Lesnícke Centrum, Lesnícky výskumný ústav Zvolen, 1-13. 
Wermelinger B. 2002. Development and distribution of predators and parasitoids during two consecutive years of an Ips typographus (Col., Scolytidae) infestation. Journal of Applied Entomology, 126, 521-527.

Wermelinger B. 2004. Ecology and management of the spruce bark beetle Ips typographus - a review of recent research. Forest Ecology and Management, 202, 67-82.

Weslien J., Schroeder L.M. 1999. Population levels of bark beetles and associated insects in managed and unmanaged spruce stands. Forest Ecology and Management, 115, 267-275.

Zhang Q.H., Schlyter F. 1995. Distribution, mortality and sex-ratio of overwintering Ips duplicatus (Co- leoptera, Scolytidae) in the soil of Picea koraiensis reserve in Inner Mongolia, China, with a model of diffusion. In: Behavior, Population Dynamics and Control of Forest Insects (eds.: F.P. Hain, S. Salom, W. Ravlin, T.L. Payne, K.F. Raffa). Ohio State University, OARDC, Wooster.

Zhang Q.H., Liu G.T., Schlyter F., Birgersson G., Anderson P., Valeur P. 2001. Olfactory responses of Ips duplicatus from inner Mongolia, China to nonhost leaf and bark volatiles. Journal of Chemical Ecology, 27, 995-1010.

Zúbrik M., Kunca A., Turčani M., Vakula J., Leontovyc R. 2006. Invasive and quarantine pests in forests in Slovakia. OEPP/EPPO Bulletin, 36, 402-408. 